\title{
Ecriture Feminine dalam Tataran Penceritaan Novel The Powerbook Karya Jeanette Winterson
}

\author{
Oleh: \\ Nisa'ul Fithri Mardani Shihab ${ }^{1}$, Aquarini Priyatna, Sri Rijati Wardiani \\ Program Studi Ilmu Sastra, Fakultas Ilmu Budaya \\ Universitas Padjadjaran \\ Email: nisa.mardani@gmail.com, HP.085279420005
}

\begin{abstract}
This writing examines the narration level in The Powerbook (2000) novel by Jeanette Winterson by focusing on the concept of ecriture feminine, referring to the structure and the form of narration. Jeanette Winterson is one of woman writers in English literature whose works indicate a form of ecriture feminine as a counter discourse for phallogocentrism. Winterson's works in the narration level exhibit the difference from the conventional narration forms. In The Powerbook, ecriture feminine in the narration level is shown in the form of fragmented narration that comes in three different forms, namely: narcissistic narrative, public narration and history demythologization. The result of the research points out that the narration form of the novel is a resistance toward phallogocentrism by demonstrating women's writing that manifests the way women make sense of their wold.
\end{abstract}

Key Words: ecriture feminine, Jeanette Winterson, narration

Abstrak. Tulisan ini mendiskusikan tataran penceritaan dalam novel The Powerbook (2000) karya Jeanette Winterson dengan berfokus pada konsep ecriture feminine atau tulisan feminin, yang mengacu kepada struktur dan bentuk narasi. Jeanette Winterson adalah salah satu penulis perempuan dalam kesusastraan Inggris yang karyanya memperlihatkan bentuk tulisan feminin sebagai wacana tandingan terhadap falogosentrisme. Karya-karya Winterson memperlihatkan perbedaan dalam tataran penceritaan dari bentuk-bentuk penarasian konvensional. Dalam novel The Powerbook, bentuk tulisan feminin dalam tataran penceritaan ditunjukkan dalam bentuk narasi yang terfragmentasi yang hadir dalam tiga bentuk berbeda, yakni narasi narsisistik, penarasian publik dan demitologisasi sejarah. Hasil penelitian menunjukkan bahwa bentuk narasi yang ditampilkan di dalam novel meresistensi wacana falogosentris dengan menampilkan bentuk tulisan perempuan yang memanifestasi cara perempuan memaknai dunia.

Kata Kunci: ecriture feminine, Jeanette Winterson, penarasian 


\section{PENDAHULUAN}

Isu seksualitas perempuan dalam sebuah karya sastra, khususnya novel, sudah banyak dibahas oleh kritisi sastra. Seksualitas dalam karya sastra tidak selalu ditampilkan di dalam isi ceritanya saja melainkan juga pada bagaimana cerita tersebut disajikan. Artinya, cara sebuah novel bertutur juga turut berpartisipasi menyampaikan tema seksualitas yang diusungnya. Salah satu penulis perempuan yang memperlihatkan hal ini di dalam karya-karyanya adalah Jeanette Winterson.

Tulisan ini mendiskusikan bagaimana novel Jeanette Winterson yang berjudul The Powerbook (2000) memperlihatkan cara bercerita yang tidak linier dan terfragmentasi sebagai sebuah perwujudan dari bentuk tulisannya yang feminin. Tulisan feminin atau ecriture feminine adalah sebuah istilah yang ditawarkan Helene Cixous di dalam esainya "The Laugh of the Medusa" (1976), yang mengacu kepada bagaimana perempuan menuliskan tubuhnya di dalam bahasa dan teks sebagai bentuk resistensi terhadap wacana falogosentris.

Cixous (1976:876) menyeru perempuan untuk menuliskan tubuhnya dengan mengatakan, “And why don't you write? Write! Writing is for you, you are for you: your body is yours, take it". Bukan hanya menulis, perempuan diseru untuk menulis dengan gayanya sendiri dengan cara mengklaim kembali tubuh mereka. Inilah yang dimaksud dengan tulisan feminin, yakni tulisan yang dibuat perempuan yang melampaui batasan-batasan sensor, pembacaan, pandangan, dan komando laki-laki (Cixous, 1981:53). Tulisan yang membebaskan diri dari komando maskulin inilah yang Cixous acu sebagai "true texts of women-female sexed texts" (Cixous, 1976: 877). Cixous juga menggaris bawahi bahwa yang diacunya sebagai feminin atau perempuan adalah bukan semata penulisnya itu melainkan teks atau tulisan yang dibuatnya. Artinya, demi meresistensi logika falusentrisme yang tidak sejalan dengan cara berpikir perempuan, Cixous mengajak perempuan untuk menulis dengan bahasanya sendiri, yakni bahasa perempuan.

Menulis dalam bahasa perempuan berarti menulis dengan cara yang berbeda dari bahasa laki-laki dan dari seksualitasnya yang terpusat pada falus. Menurut Irigaray (1985:25), "women's desire would not be expected to be the same language as man's: women's desire has doubtless been submerged by [man's] logic..." Oleh karena itu, berbeda dari tulisan laki-laki dan seksualitasnya yang terpusat, seksualitas perempuan tidak terbatas pada satu area tubuhnya melainkan menyebar (Irigaray, 1985) sehingga tercermin pada bentuk tulisannya yang tidak linier seperti pada tulisan konvensional, melainkan terpecah-pecah atau terfragmentasi. Bentuk tulisan demikian dibahas Lanser dalam "Towards Feminist Narratology" (1989) dengan menyoroti pentingnya hal tersebut sebagai sebuah resistensi tulisan perempuan terhadap logika falogosentrisme.

Lanser (1989:466), mengutip Maria Brewster, mengatakan bahwa alur dalam pandangan universal merefleksikan "discourse of male desire recounting itself through the narrative of adventure, project, enterprise, and conquest", sehingga alur dalam cerita perempuan yang tidak demikian "is condemned simply to negative definintion - plotlessness, or story without plot”" (Lanser, 1986: 465). Bentuk narasi 
yang seperti tidak beralur inilah yang saya temukan dalam novel The Powerbook (2000) karya Jeanatte Winterson. Alur yang terfragmentasi di dalam The Powerbook dibangun lewat keseluruhan narasi yang memiliki latar yang bergantiganti antara masa kini, masa lalu, dan masa depan.

Selain narasi yang terpecah-pecah, sebuah tulisan feminin juga dapat memperlihatkan perbedaannya dari wacana falogosentris dalam bentuk sebuah narcissistic narrative atau yang selanjutnya akan diacu dengan narasi narsisistik. Istilah ini datang dari teori Linda Hutcheon (1980) yang merujuk pada teks yang menyadari bahwa dirinya adalah sebuah teks atau fiksi. Menurut Hustcheon (1980), bentuk sebuah narasi yang memiliki kesadaran terhadap kediriannya menjadi penting karena meminimalisasi efek alienasi yang diciptakan sebuah narasi konvensional. Dengan kesadarannya sebagai sebuah fiksi, sebuah teks memberi peluang bagi pembaca untuk turut serta dalam proses penciptaannya. Bentuk narasi demikian saya temukan pada novel The Powerbook.

Selain itu, tidak hanya berhenti pada titik menyadari statusnya sebagai sebuah teks, tulisan feminin juga dapat ditandai dengan turut menyadarkan pembaca akan kefiksiannya dengan cara public narration atau yang selanjutnya diacu sebagai penarasian publik, yakni penarasian yang ditujukan kepada narratee atau pembaca di luar semesta tekstual (Lanser, 1989). Menurut Lanser (1989), bentuk narasi publik dalam tulisan feminin menjadi penting karena menandai upaya perempuan untuk keluar dari anggapan bahwa perempuan berelasi dengan ranah privat sedang ranah publik merupakan milik laki-laki. Gejala penarasian publik juga diperlihatkan di dalam The Powerbook.

Anggapan lainnya yang juga berupaya diresistensi di dalam sebuah tulisan feminin adalah keagungan sejarah atau pembedaan antara sejarah yang dianggap nyata dan fiksi yang dianggap rekaan. Kilic (2004) mengistilahkan teks yang melakukan hal tersebut dengan demitologisasi sejarah. Hal ini menjadi penting pula karena dengan cara meleburkan antara yang sejarah dan yang fiksi, sebuah teks memproblematisasi validitas sejarah serta validitas pandangan tradisional yang mengatakan bahwa sejarah dan fiksi adalah dua hal yang terpisah (Hutcheon sebagaimana dibahas Kilic, 2004: 127).

Dengan mempertimbangkan pentingnya bentuk-bentuk narasi di atas dalam sebuah tulisan feminin, maka penelitian ini mengidentifikasi bagaimana permainan terhadap konvensi narasi tradisional digambarkan di dalam novel, dan bagaimana permainan ini mensiginifikansi upaya teks berbicara dalam bentuk tulisan feminin. Dengan demikian, maka penelitian ini bertujuan untuk menggambarkan permainan novel terhadap standar narasi tradisional dan menunjukkan upaya teks untuk berbicara dalam bahasa feminin lewat permainan-permainan tersebut.

\section{METODE PENELIITIAN}

Novel The Powerbook (2000) karya Jeanette Winterson memperlihatkan permainan terhadap konvensi narasi tradisional dengan cara yang bervariasi. Oleh karena itu, dalam melakukan penelitian ini mula-mula yang saya lakukan adalah mengelompokkan gejala-gejala tekstual di dalam novel berdasarkan kesamaan 
isunya. Selanjutnya, potongan-potongan teks di bawah isu yang sama dibahas menggunakan teori-teori yang berkesuaian.

Isu besar yang menaungi isu-isu khusus di dalam novel adalah narasi yang terfragmentasi karena terdiri dari potongan kisah masa lalu, masa kini, dan masa depan. Untuk membahas isu ini, saya mengaplikasikan naratologi feminis Susan Lanser yang memandang bahwa tulisan feminin kerap dianggap tidak beralur atau "plotless" karena tidak mengalir dalam garis lurus.

Selanjutnya, saya masuk ke dalam pembahasan isu-isu khusus di bawah payung besar tersebut. Yang pertama adalah kesadaran teks terhadap dirinya sendiri. Untuk membahasanya, saya menggunakan teori Linda Hutcheon tentang narasi narsisitik dalam bukunya Narcissistic Narrative The Metafictional Paradox (1980).

Selanjutnya, saya membahas penarasian publik yang ditandai dengan adanya pengacuan novel terhadap narratee di luar semesta tekstual. Untuk mendiskusikannya, saya memanfaatkan teori Lanser (1989) yang beragumen bahwa penarasian publik dalam tulisan feminin menjadi penting karena dalam wacana falogosentris, publik dianggap sebagai domain laki-laki sedangkan perempuan direlasikan dengan ranah privat.

Selanjutnya, isu yang terakhir adalah tentang demitologisasi sejarah. Novel ini kerap memperlihatkan alusi terhadap legenda dan sejarah sehingga memperlihatkan adanya peleburan antara fiksi dan yang dianggap nonfiksi. Untuk menganalisisnya, saya memanfaatkan tulisan Kilic (2004) dalam "Demythologizing History: Jeanette Winterson's Fictions and His/Tories" yang membahas peleburan fiksi dan sejarah di dalam karya-karya Winterson secara umum. Semua tahapan ini dilakukan untuk menjawab identifikasi masalah pada bagian sebelumnya untuk kemudian bermuara pada simpulan penelitian.

\section{HASIL DAN PEMBAHASAN}

Pembahasan tentang tataran penceritaan The Powerbook saya lakukan dengan mula-mula mendiskusikan karya Jeanette Winterson dan bagaimana secara umum karyanya menunjukkan bentuk tulisan feminin. Untuk menunjukkannya, saya mendiskusikan tiga karyanya yang lain yang telah saya bahas dalam penelitian terdahulu (Shihab, 2014). Hal ini relevan untuk memberikan konteks sebelum lebih jauh melakukan diskusi terhadap The Powerbook. Pembahasan The Powerbook dilakukan dengan terlebih dahulu menyinggung ulasan kritisi terhadap novel ini. Hal ini dilakukan untuk memosisikan penelitian saya di antara ulasanulasan tersebut.

\section{Jeanette Winterson dan Tulisan Feminin}

Winterson mulai dikenal sejak kemunculan novel pertamanya Oranges are not the only Fruits yang meraih Whitbread Award for a First Novel pada tahun 1985. Novel ini bercerita tentang kehidupan seorang gadis remaja bernama Jeanette yang harus menghadapi tekanan dari keluarga dan lingkungannya yang religius ketika dia mulai menyadari bahwa dirinya adalah seorang lesbian. Resistensi tokoh utama 
Jeanette terhadap norma-norma di sekelilingnya tidak hanya mewujud dalam bentuk isi cerita namun juga pada teknik penceritaan.

Novel ini menyajikan cerita lewat alur yang tidak linier yang dibangun dengan pergantian waktu cerita (time of narrated) dan waktu penceritaan (time of narrating) tanpa pemarkah yang kentara. Ketidaklinieran alur di dalam novel juga dibangun dengan cara teks memasukkan narasi lain di tengah-tengah narasi utama. Narasi yang diselipkan ini berbentuk seperti dongeng dan tidak memiliki keterhubungan alur dengan kisah Jeanette sebagai narasi utama.

Teknik penarasian yang tidak linier juga saya temukan di dalam novel Winterson lainnya, yakni The Passion (1987). Novel yang berlatarkan era Napoleon ini menggunakan teknik penceritaan sudut pandang orang pertama. Naratornya terdiri dari dua tokoh yang bergantian menuturkan cerita dari sudut pandangnya masingmasing, yakni seorang tentara laki-laki bernama Henri dan tokoh perempuan bernama Villanelle. Dari segi cerita, novel ini mempermainkan normatifitas dengan menampilkan tokoh Villanelle yang bekerja di sebuah kasino dengan menyamar sebagai laki-laki. Ia juga dikisahkan jatuh cinta dan menjalin hubungan dengan seorang perempuan.

Dari segi penceritaan, ketidaklinearan alur di dalam novel ini dibangun lewat pergantian kedua narator di dalam satu tubuh narasi yang sama tanpa pemarkah yang kentara. Selain alur yang tidak linier, novel ini memperlihatkan permainan terhadap teknik narasi tradisional dengan memperlihatkan kesadaran bahwa dirinya adalah teks dan dengan mengacu narratee di luar teks. Selain itu, novel ini juga meleburkan dunia Henry yang rasional dan Villanelle yang magis dan dalam pandangan Henry 'tidak masuk akal'.

Teknik demikian juga saya temukan di dalam novel Winterson yang lain, yakni Gut Symmetries (1997). Novel ini bercerita tentang hubungan cinta antara tiga tokoh utama yakni Stella, Alice, dan Jove. Seperti dua novel sebelumnya, dari segi cerita novel ini meresistensi heteronormativitas dengan menyuguhkan kisah percintaan antara dua tokoh perempuan, Stella dan Alice.

Dari sisi penceritaan, novel ini juga memiliki kemiripan teknik dengan dua novel sebelumnya. Gut Symmetries dikisahkan bergantian lewat sudut pandang ketiga tokoh tadi. Ketidakliniearan alur novel ini dibangun lewat pergantian waktu cerita dan penceritaan serta pergantian narator di dalam satu tubuh narasi yang sama tanpa pemarkah yang kentara. Selain itu, Gut Symmetries memperlihatkan kesadaran dirinya yang sebuah teks serta melakukan pengacuan terhadap narratee di luar teks.

Bentuk-bentuk permainan narasi di dalam ketiga novel Winterson di atas juga saya temukan pada novel The Powerbook, baik dengan cara yang relatif mirip maupun dengan bentuk yang berbeda. Untuk mendiskusikannya, saya terlebih dahulu memperlihatkan dua sudut pandang yang berbeda dari dua ulasan kritisi sastra terhadap novel ini. 


\section{Tataran Penceritaan dalam The Powerbook}

Jeanette Winterson adalah seorang sastrawan Inggris yang dikenal dengan novelnovelnya yang mendekonstruksi batasan-batasan narasi konvensional (Méndez, 2010:7). Permainan karya-karya Winterson ini juga dipandang sebagai upaya mentransgresi narasi falogosentris (Front, 2010) dengan menyuguhkan narasi yang tidak linier seperti yang ditemukan dalam karya sastra tradisional (TerzievaArtemis, 2007:1).

Penilaian semacam itu saya temukan dalam ulasan Elaine Showalter yang memandang bahwa The Powerbook merupakan "...literary junk food ... with nothing to say" (Showalter, 2000). Showalter mengklaim bahwa kekecewaannya memang bukan terletak pada gaya penarasian The Powerbook melainkan pada tema cinta dan perselingkuhan yang kerap diusung Winterson di karya-karyanya yang lain. Kendati demikian, saya melihat ulasan Showalter sebagai salah satu contoh kasus yang dibicarakan Terzieva-Artemis (2007:1), bahwa "Jeanette Winterson is a novelist who has conspicuously defied traditional literary standards in her work in the past twenty years and yet critics are constantly tempted to define her against such standards".

Sudut pandang yang berbeda saya temukan dari ulasan Kelly Kellaway. Berbeda dari ulasan Showalter yang berfokus kepada aspek tematis, Kellaway lebih menitikberatkan penilaiannya kepada gaya penceritaan The Powerbook. Ia dengan lebih optimis memandang bahwa "[t] he computer is, for [Winterson], a conceit, an invitation to explore, a way of making narratives come and go faster than the speed of light. It never holds her up or back. Her writing is graceful, jargon-free, light as thistledown" (Kellaway, 2000). Kellaway, seperti yang disinggung TerzievaArtemis di atas, memilih untuk menilai novel Winterson dengan melepaskan kerangka standar literer tradisional yang cenderung berfokus pada isu tematis semata seperti yang Showalter lakukan.

Perbedaan fokus ulasan Showalter dan Kellaway di atas menurut saya dapat dikaitkan dengan terminologi Lanser yang berpendapat bahwa teks terdiri dari dua tataran, yakni isi cerita atau histoire dan cara cerita itu disuguhkan yakni récit. Menurutnya, "récit and histoire, rather than being separate elements, converge, so that telling becomes integral to the working out of story" (Lanser,1989:466). Dengan demikian, terlepas dari perbedaan titik berat Showalter dan Kellaway, saya berpendapat bahwa pentingnya The Powerbook terletak pada kedua unsur novel dan bagaimana keduanya saling berkelindan untuk menghasilkan keutuhan narasi. Oleh karena itu, sebelum mendiskusikan secara khusus gejala-gejala tekstual yang ditampilkan di dalam tataran récit yang menjadi fokus penelitian ini, saya terlebih dahulu membicarakan isi cerita novel atau histoire.

Pada tataran histoire, novel ini berpusat pada seorang penulis dunia maya bernama Ali yang jatuh cinta kepada seorang perempuan bersuami. Tokoh perempuan ini tidak pernah disebutkan namanya di keseluruhan novel. Novel hanya memberikan petunjuk tentang identitas tokoh sebagai seorang perempuan dengan mengacunya dalam kata ganti "she". Berbeda dari tokoh perempuan tak bernama ini, teks tidak memberitahukan secara eksplisit jenis kelamin Ali yang berperan sebagai narator. 
Novel hanya memberikan siratan bahwa Ali adalah seorang perempuan di beberapa bagian cerita. Dalam sebuah bab berlatar masa lalu, terdapat kisah bahwa Ali adalah seorang perempuan yang menyamar menjadi laki-laki.

Gejala-gejala ini memperlihatkan permainan novel terhadap wacana seks dan gender. Novel memperlihatkan bahwa, sebagaimana dikatakan Butler (1990:7), seks dan gender mungkin bukanlah hal berlainan. Pengaburan identitas Ali dan tokoh perempuan tanpa nama tadi sejalan dengan pandangan Butler (1990) bahwa seks dan gender adalah kerangka inteligibilitas yang membantu, namun juga membatasi, upaya seseorang dalam mengidentifikasi seorang manusia dan bahwa seks dan gender adalah sebuah pertunjukan.

Tataran histoire di atas sedikit banyak menunjukkan bagaimana posisi novel terhadap wacana falogosentris. Hal-hal yang dianggap normatif dipermainkan di dalam novel dengan memperlihatkan sebuah identitas (gender dan seksual) yang cair. Isi cerita yang demikian juga didukung lewat teknik penceritaannya atau récit.

Pada tataran récit, secara umum The Powerbook memperlihatkan narasi yang terpecah sehingga terkesan seperti tidak beralur. Novel ini menampilkan realitas jamak yang dibangun lewat komposisi latar waktu masa lalu, masa kini, dan masa depan. Komposisi kala yang terus berganti-ganti ini memberikan kesan narasi yang terpecah-pecah dan terbagi-bagi, sehingga mengaburkan gambaran utuh dari cerita utama yang hendak dibawakan. Lanser (1989:464) berpendapat bahwa dalam bingkai tradisional, gaya demikian kerap dicap sebagai narasi yang tidak memiliki alur sehingga terkesan seolah tidak memiliki cerita, atau bahkan tidak dapat dikatakan sebagai narasi sama sekali.

Tiap-tiap kala di dalam The Powerbook disajikan di dalam bab yang berbeda-beda. Bab yang menyiratkan masa kini bercerita tentang Ali di depan layar komputer. Ia bekerja membuat cerita sesuai pesanan korespondennya. Bab yang menyiratkan waktu lampau merupakan cerita yang Ali tulis itu. Kisah-kisah ini terdiri dari campuran legenda terkenal seperti King Arthur dan Francesca da Rimini, Lancelot dan Guinevere, atau kisah sejarah seperti Giovanni de Castro dan George Mallory. Selain kisah-kisah ini, bab yang berlatar waktu lampau juga berisi tentang cerita masa kecil Ali bersama orang tua angkatnya. Sementara itu, bab yang menyiratkan masa depan bercerita tentang hubungan percintaan Ali dengan perempuan bersuami yang tidak pernah disebutkan namanya.

Ketiga kala yang berbeda namun dimampatkan di dalam satu narasi besar yang sama yakni novel The Powerbook membangun efek narasi yang terpecah dan seperti tidak berhubungan satu sama lain. Namun demikian, Lanser (1989) berargumentasi bahwa sebenarnya dibalik tulisan perempuan yang seperti tidak beralur ini terdapat sebuah plot yang subversif yang menandai upaya perempuan untuk memahami dunianya. Caranya memahami dunia bukan hanya terlihat dari isi cerita yang dituturkan namun juga dari caranya bercerita dan tindakan bercerita itu sendiri. Cara bercerita tulisan feminin dengan demikian mengambil bentuk yang berbeda dari yang diperlihatkan dalam narasi tradisional. Dalam The Powerbook, 
cara bercerita atau yang diacu Lanser dengan tataran récit mewujud dalam berbagai bentuk-bentuk yang dibahas di bawah ini.

Yang pertama adalah kesadaran teks akan dirinya sendiri, atau yang disebut dengan narasi narsisistik. Hal ini ditemukan dalam beberapa bagian novel, seperti misalnya:

"This is just a story" (Winterson, 2000: 27)

"I warned you that the story might change under my hand." (Winterson, 2000: 83)

"I keep telling this story - different people, different places, different timesbut always you, always me, always this story, because a story is a tightrope between two worlds." (Winterson, 2000: 119)

Penggalan-penggalan teks di atas memperlihatkan bagaimana The Powerbook menyadari statusnya sebagai sebuah cerita ("story") atau sebuah fiksi. Dalam terminologi Linda Hutcheon, fiksi yang demikian disebut dengan narasi narsisistik atau fiksi yang memperlihatkan kesadarannya sebagai sebuah teks dengan merujuk dirinya sendiri (Hutcheon, 1980:1). Hutcheon (1980) memandang bahwa bentuk narasi yang self-conscious menjadi penting karena melemahkan pengagungan terhadap pengarang yang menciptakan jarak antara pengarang dan pembaca. Hutcheon juga berargumentasi bahwa dengan memendekkan jarak tersebut, narasi narsisistik mengurangi efek alienasi yang diciptakan, dan memberikan pembaca kesempatan untuk turut mengalami proses penciptaan sebuah fiksi.

Melibatkan pembaca ke dalam sebuah fiksi juga mewujud lebih khusus dalam gejala selanjutnya, yakni penarasian publik. Penarasian publik adalah sebuah narasi yang ditujukan kepada pembaca di luar teks baik secara eksplisit maupun implisit (Lanser, 1989:461). Di dalam The Powerbook, bentuk penarasian publik ditampilkan dengan cara narator sudut pandang orang pertama (Ali dalam bentuk "I") merujuk pembaca (“you”) seperti yang diperlihatkan dalam penggalan di atas. Selain itu, perujukan teks terhadap pembaca juga diperlihatkan dalam penggalanpenggalan berikut ini:

“Then she made a speech. I suppose you can guess the line." (Winterson, 39)

"You can change the story. You are the story" (Winterson, 2000:244).

"This is the story of Francesca da Rimini and her lover Paolo. You can find it in Boccaccio. You can find it in Dante. You can find it here." (Winterson, 2000: 123)

"In this life you have to be your own hero. By that I mean you have to win whatever it is that matters to you by your own strength and in your own way." (Winterson, 2000: 155)

Penggalan-penggalan teks di atas memperlihatkan bagaimana novel merujuk kepada narratee di luar teks atau pembaca dengan kata ganti "you". Dalam kerangka ecriture feminine, penarasian publik menjadi penting karena wacana falogosentris merelasikan perempuan dengan ranah privat dan laki-laki dengan ranah publik (Lanser, 1980). Dengan cara-cara di atas, novel The Powerbook 
memperlihatkan bahwa tulisan feminin mampu merangkul yang diistilahkan Lanser (1980) dengan audiens publik dan dengan demikian mengajak pembaca untuk turut terlibat dalam kisah dan juga proses pengisahannya. Pelibatan ini menjadi penting karena melalui wacana ecriture feminine, narator di dalam cerita "[is] sharing an experience so that the listener's life may complete the speaker's tale (Lanser, 1986:467).

Tidak hanya mengajak pembaca masuk ke dalam kisahnya, The Powerbook juga turut melibatkan pembaca dalam proses penciptaan sebuah sejarah dengan cara memasukkan berbagai kisah-kisah legenda dan sejarah. Seperti yang telah disinggung pada bagian awal pembahasan, salah satu cara yang membuat alur novel ini terfragmentasi adalah dimasukkannya kisah-kisah berlatar masa lalu. Kisahkisah ini beralusi kepada sejarah atau beberapa legenda populer dalam kesusastraan Barat.

Kisah yang berlatar masa lalu misalnya terdapat pada bab Open Hard Drive. Berlatar tahun 1634, bab ini bercerita tentang seorang perempuan bernama Ali yang ditugasi untuk menyelundupkan bibit tulip dari Turki ke Belanda. Untuk melakukannya, Ali harus menyamar menjadi seorang laki-laki. Kisah ini bercerita bahwa asal mula Belanda terkenal dengan tulipnya adalah berkat keberhasilan Ali membawa bibit tulip tersebut, seperti yang ia katakan dalam pembukaan ceritanya, "In the sixteenth century the first tulip was imported to Holland from Turkey. I know-I carried it myself" (Winterson, 2000:9).

Selain kisah Ali dan tulip, bab lainnya yang beralusi kepada legenda atau sejarah bab yang berjudul Really Quit?. Bab ini bercerita tentang Giovanni de Castro yang kembali ke Italia dari perjalanannya di Levant. Kedatangannya kembali ini membawa keuntungan besar bagi pihak Italia karena Giovanni berhasil menemukan tujuh gunung yang kaya akan alum atau tawas, sehingga Italia tidak perlu lagi mengimpor tawas dari Turki. Dalam pembukaan bab ini, teks menuturkan kisah di atas dari sudut pandang Pius sebagai pencerita dalam penggalan di bawah ini:

"In 1460 Giovanni de Castro, godson of Pope Pius II, returned to Italy from the Levant. In his memoirs, Pius himself described what happened.

[space]

While Giovanni was walking through the forested mountains, he came on a strange kind of herb." (Winterson, 2000: 221)

Paragraf pertama pada kutipan di atas memperlihatkan pembukaan kisah yang dituturkan narator mahatahu yang memperkenalkan narator selanjutnya yang akan mengambil alih kegiatan bercerita. Narator selanjutnya adalah Pius yang kisahnya datang di paragraf kedua, terpisahkan oleh spasi dari paragraf pertama. Selanjutnya, ketika kisah penemuan tawas yang dibawakan dari sudut pandang Pius tersebut berakhir, teks membalik sudut pandang dengan menuturkan kisah dari sudut pandang Giovanni sendiri. 


\author{
"Giovanni takes up the story himself. \\ [space] \\ "All day I had been searching for a pearl earring lost in my chamber by \\ my mistress." (Winterson, 2000: 222)
}

Giovanni yang di dalam penggalan sebelumnya diacu dengan kata ganti orang ketiga " $h e$ " karena berada di dalam penceritaan Pope Pius selaku penutur kisah, berganti menjadi " $P$ " dan bercerita lewat sudut pandangnya sendiri. Berbeda dari kisah Pius yang mengatribusi penemuan Giovanni sebagai hal yang agung, kisah versi Giovanni sendiri malah memperlihatkan bahwa penemuannya akan tawas merupakan ketidaksengajaan saat ia sibuk mencari antingnya yang hilang.

Dua contoh alusi sejarah di atas, yakni kisah Ali dan tulip Belanda, serta kisah Giovanni dan tawas Italia, memperlihatkan apa yang diistilahkan Kilic (2004) sebagai demitologisasi sejarah. Artinya pertama, kedua contoh di atas menandai kesengajaan teks untuk berargumentasi bahwa sejarah bukan merupakan sesuatu yang ajeg. Kedua, dimasukkannya kisah-kisah yang beralusi kepada sejarah di dalam narasi utama novel memperlihatkan adanya peleburan antara yang dianggap nyata dan yang diketahui sebagai fiksi, yang menandai upaya teks untuk mendobrak mitos bahwa sejarah adalah kenyataan. Dengan demikian, novel ini “... problematize [s] the validity of history, as well as the validity of the traditional view that the historical and fictional are separate" (Hutcheon dalam pembahasan Kilic, 2004: 127).

\title{
KESIMPULAN
}

Pembahasan tataran narasi The Powerbook memperlihatkan bahwa novel ini bercerita dalam tulisan feminin lewat alurnya yang tidak linier, yakni terpecahpecah atau terfragmentasi. Fragmentasinya dibangun lewat kisah-kisah yang terdiri dari kisah masa lalu, masa kini, dan masa depan yang dibawakan di dalam bab yang berbeda-beda. Alur yang demikian merupakan salah satu kekhasan tulisan feminin yang menandai upayanya untuk memahami dunianya.

Selain bahwa tulisan feminin dalam The Powerbook ditandai secara umum dari alur yang terfragmentasi, novel ini bertutur dalam bahasa feminin lewat tiga cara-cara yang lebih khusus yang tiap-tiapnya menandai adanya upaya untuk memberikan wacana tandingan terhadap falogosentrisme. Yang pertama, dengan bentuk narasi narsisistik, novel ini memperlihatkan kesadaran sebagai sebuah fiksi dan dengan demikian melemahkan keagungan pengarang dan memendekkan jarak antara pengarang dan pembaca. Yang kedua, dengan bentuk penarasian publik, novel ini memperlihatkan bahwa pembaca yang pada narasi konvensional dianggap sebagai entitas yang berada di luar semesta tekstual diajak masuk dan turut serta dalam pengalaman di dalam teks. Ketiga, dengan mendemitologisasi sejarah, novel ini melawan gagasan dalam wacana falogosentris yang menganggap sejarah adalah sesuatu yang ajek. Dengan meleburkan batasan antara yang dianggap fakta dan fiksi, novel ini menawarkan sebuah pandangan bahwa keduanya bukan hal yang berbeda, melainkan sama-sama merupakan sebuah kisah yang dibuat. 


\section{DAFTAR PUSTAKA}

Cixous, H. Autumn,1981. Castration or Decapitation. (A. Kuhn, Ed.) Signs, Vol. 7, No. 1, 41-55.

Cixous, H. Summer, 1976. The Laugh of the Medusa. (K. Cohen, \& P. Cohen, Eds.) Signs, Vol. 1, No. 4., 875-893.

Front, S. 2009. Transgressing Boundaries in Jeanette Winterson's Fiction. Didapatkan dari https://www.peterlang.com/view/product/63799

Hutcheon, L. 1980. Narcissistic Narrative The Metafictional Paradox. Ontario: Wilfrid Laurier University Press.

Irigaray, L. 1985. This Sex which is not One. This Sex which is not One, 23-33.

Kellaway, K. 2000, Agustus 27. Jeanette Winterson's new novel, The PowerBook, is a virtuoso trip into virtual reality. Diakses pada October 2016, dari The Guardian.

Kilic, M. Ö. 2004, Desember. Demythologizing History: Jeanette Winterson's Fictions and His/Tories. Feminismo, 127-134.

Lanser, S. 1989. Towards Feminist Narratology. 453-469.

Méndez, F. C. 2010. The Limitless Self: Desire and Transgression in Jeanette Winterson's Oranges Are Not the Only Fruit and Written on the Body. Master Thesis, Universitat de Barcelona. Diakses pada November 2016, dari http://diposit.ub.edu/dspace/handle/2445/11225

Rossitsa Terzieva-Artemis. 2007. "Desiring," or Simply Human: Jeanette Winterson's Written on the Body. Performing Identity/Crossing Borders: The Cyprus Symposium. Diakses pada November 2016, dari cicac.tru.ca/media/artemis_2007.pdf

Shihab, N. F. 2014. L'ecriture Feminine sebagai Wacana Tandingan dalam Tiga Novel Jeanette Winterson (Skripsi). Universitas Padjadjaran, Sastra Inggris. Jatinangor: Universitas Padjadjaran.

Showalter, E. 2000, September 2. Jeanette Winterson's The.Powerbook is lost in cyberspace. Diakses pada Oktober 2016, dari The Guardian: https://www.theguardian.com/books/2000/sep/02/fiction.jeanettewinterson 1

Winterson, J. 2000. The PowerBook. London: Jonathan Cape. 